\title{
Induction of secondary metabolite production by UV-C radiation in Vitis vinifera L. Öküzgözü callus cultures
}

\author{
Emine Sema Cetin
}

\begin{abstract}
Background: The aim of the present work was to examine the role of UV-C irradiation on the production of secondary metabolites (total phenolic, total flavanols, total flavonols, catechin, ferulic acid and trans-resveratrol in phenolic compounds and $\mathrm{a}-, \beta-, \gamma$ - $\delta$-tocopherols) in callus cultures. Studies on the effects of UV-C treatment on callus culture are seldom and generally focused on UV-B. However UV-C radiation play an important role in accumule secondary metabolites.

Results: In this study, callus cultures from Öküzgözü grape cultivar were initiated from leaf petiole explants. Calli formed after 6 weeks on the medium supplemented with $0.5 \mathrm{mg} \mathrm{L}^{-1}$ benzylaminopurine (BA), $0.5 \mathrm{mg} \mathrm{L}^{-1}$ indole acetic acid (IAA) on B5 media. Callus tissues were exposed to UV-C irradiation at 10, 20 and $30 \mathrm{~cm}$ distances from the UV source for 5 and 10 minutes and samples were collected at hours 0, 24 and 48.

Conclusions: The greatest total phenolic content $\left(155.14 \mathrm{mg} 100 \mathrm{~g}^{-1}\right)$ was detected in calli exposed to UV-C for $5 \mathrm{~min}$ from $30 \mathrm{~cm}$ distance and sampled after $24 \mathrm{~h} .24 \mathrm{~h}$ and $48 \mathrm{~h}$ incubation times, $30 \mathrm{~cm}$ and 5 min were the most appropriate combination of UV-C application in total flavanol content. Maximum total flavonol content $\left(7.12 \mathrm{mg} 100 \mathrm{~g}^{-1}\right)$ was obtained on $0 \mathrm{~h}, 5 \mathrm{~min}$ and $20 \mathrm{~cm}$ combination. The highest (+)- catechin accumulation $\left(8.89 \mathrm{mg} \mathrm{g}^{-1}\right.$ ) was found in calli with $10 \mathrm{~min}$ UV-C application from $30 \mathrm{~cm}$ distance and sampled after $48 \mathrm{~h}$. Ferulic acid content increased 6 fold in Öküzgözü callus cultures $\left(31.37 \mu \mathrm{g} \mathrm{g}^{-1}\right)$ compared to the control group. The greatest trans-resveratrol content $\left(8.43 \mu \mathrm{g} \mathrm{g}^{-1}\right)$ was detected in calli exposed to UV-C for 5 min from $30 \mathrm{~cm}$ distance and sampled after $24 \mathrm{~h}$. The highest a-tocopherol concentration was found in calli exposed to UV-C for $10 \mathrm{~min}$ from $30 \mathrm{~cm}$ distance and sampled after $24 \mathrm{~h}$. As a conclusion, it was showed that UV-C radiation had remarkable promoting effects on the accumulation of secondary metabolites in the calli of Öküzgözü grape cultivar.
\end{abstract}

Keywords: Callus, Secondary metabolite, UV-C treatment

\section{Background}

Secondary metabolites are organic compounds synthesized by plants however they are not directly essential for photosynthesis, reproduction, respiration or other primary functions. The chemicals have extremely diverse effects. They often play an important role in the plant defense system. Some of them contribute to pollination and serve as protection from drought, salinity and UV radiation [1]. Due to their large biological activities, plant secondary

Correspondence: esemacetin@gmail.com

Department of Horticulture, Faculty of Agriculture and Natural Science, Bozok University, Yozgat 66200, Turkey metabolites have been used for centuries by humans as medicines, flavorings or recreational drugs.

Several metabolites in plants have preventive roles in diseases caused by oxidative stress [2]. The susceptibility of the human body to peroxidative damage is related to the efficiency of antioxidant defences [3]. Some secondary metabolites (e.g. polyphenols and tocopherols) have been shown to protect reactive oxygen species [4]. It is likely that they may provide unique resources for pharmaceuticals and may possess beneficial medicinal properties in humans [5]. Therefore these molecules, can be applicable to our diet and have been shown to play a possible role in the prevention of several chronic diseases [6]. 
The phenolic compound family is huge and comprises a complex group of compounds varying from simple phenols to highly polymerised compounds. Polyphenols have been extensively studied and are reported to possess several biological activities. Numerous studies have focused on their anti-mutagenic chemopreventive and anti-carcinogenic activities $[7,8]$. Polyphenols have been shown to inhibit a wide range of enzymes such as phosphodiesterase and ATPases [7] and to enhance the production of glutathione (GSH) and GSH-related enzymes [9].

Tocopherols, collectively known as vitamin E, which are important secondary metabolites are lipidsoluble antioxidants and exclusively synthesised by photosynthetic organisms. The four known tocopherol forms $(\alpha, \beta, \gamma$ and $\delta$ ) have the chemical structure consisting of a polar chromanol head group and a non-polar prenyl tail in common. In general, $\alpha$-tocopherol is the major vitamin E form present in plant tissues, while $\gamma$-tocopherol accumulates to higher levels in most seeds [10]. Vitamin E has attracted much attention clinically because of its potential to be a very useful drug, and has been widely studied for its antiaging, anticarsinogenesis, antiatherosclerosis effects [11].

A number of strategies have been developed which aims at enhancing product formation from callus cultures. The abiotic elicitation is one of the methods for increasing the secondary metabolite production in plant cell tissue cultures. Because of the importance of the secondary metabolites, including phenolics and tocopherols on human health and nutrition, in this study, the aim was to determine the effects of UV-C irradiation as an abiotic elicitor on secondary metabolit production on Vitis vinifera L. cv. Öküzgözü calli.

\section{Results and discussion}

Phenolic composition of the callus samples changed significantly according to the irradiation distance, irradiation duration and incubation time $(\mathrm{P} \leq 0.05)$ and the data were given at Table 1 . Total phenolic contents of the callus samples were estimated with Folin-Ciocalteu colorimetric method and UV-C irradiation seems to be an effective factor on total phenolic content. Total phenolic contents were higher on irradiated calli than control calli. The greatest total phenolic content $(155.14 \mathrm{mg}$ $100 \mathrm{~g}^{-1}$ ) was detected in calli exposed to UV-C for $5 \mathrm{~min}$ from $30 \mathrm{~cm}$ distance and sampled after $24 \mathrm{~h}$, while the lowest values were found in control calli sampled after $48 \mathrm{~h}$.

Total flavanol contents were also positively affected by the UV-C irradiation. Provided that $24 \mathrm{~h}$ and $48 \mathrm{~h}$ incubation times, $30 \mathrm{~cm}$ and $5 \mathrm{~min}$ was the most appropriate combination of UV-C application in terms of total flavanol content. The lowest total flavanol contents as well as total phenolic contents were obtained from the control calli.

Total flavonol contents were significantly higher at UV treatments when compared to control.

Maximum total flavonol content $\left(7.12 \mathrm{mg} 100 \mathrm{~g}^{-1}\right)$ was obtained when incubation time, irradiation duration and irradiation distance were set to be $0 \mathrm{~h}, 5 \mathrm{~min}$ and $20 \mathrm{~cm}$ above the calli, respectively. Present results show that irradiation with UV-C light enhances phenolic production by callus cultures of Öküzgözü grape cultivar.

In this study, not only the total phenolic, flavanol and flavonol contents were determined by spectrophotometric methods, but also some individual phenolics (only detectable) including $(+)$-catechin, ferulic acid and trans-resveratrol were defined by HPLC. HPLC method for analyzing phenolics in the samples has some advantages such as easy and fast procedure for the preparation of the samples, possibility of quantification of diverse phenolics, the precision, accuracy and low detection limits $d$ which enable its application to both grape and wine [12].

$(+)$ - Catechin is the most abundant flavanoid in grape seed, skin and wine [13,14]. (+)- catechin has some beneficial effects on human health. It prevents LDL oxidation and has antifungal effects $[15,16]$. For these reasons, $(+)$ - catechin accumulation regulated with the UV$\mathrm{C}$ treatment was determined in this study. The irradiation duration and distance, as well as the incubation time appeared to be the major factors influencing the accumulation of $(+)$ - catechin. The highest $(+)$ - catechin accumulation (8.89 $\mathrm{mg} \mathrm{g}^{-1}$ ) was found in calli with $10 \mathrm{~min}$ UV-C application from $30 \mathrm{~cm}$ distance and sampled after $48 \mathrm{~h}$. On the other hand, the lowest values were detected in control calli.

Stimulation of the synthesis of proanthocyanidins by UV radiation, including catechin, a monomer of proanthocyanidin, might be explained by the fact that they acts as an absorbant in the UV region of the spectrum and therefore capable of protecting plant cells from the harmful effects of UV [17].

Ferulic acid, like many phenols, has antioxidant activity [18]. Ferulic acid was the phenolic compound which best responded to UV-C irradiation among all phenolics. Ferulic acid content increased 6 fold in Öküzgözü callus cultures $\left(31.37 \mu \mathrm{g} \mathrm{g}^{-1}\right)$ compared to the control group.

Present results confirm that the elicitation with UV stimulates production of some phenolics in grape callus cultures. Chappel and Hahlbrock [19] claimed that UV light is required for flavonoid production, and enhances phenylalanine ammonia lyase (PAL) and chalcone synthase (CHS) mRNAs in parsley cell cultures. Similarly, Antognoni et al. [20] studying on Passiflora callus cultures reported that callus cultures treated with UV showed a higher flavonoid production compared to 
Table 1 The effects of UV-C treatment on phenolic compounds in Öküzgözü calli

\begin{tabular}{|c|c|c|c|c|c|c|c|c|}
\hline $\begin{array}{c}\text { Irradiation } \\
\text { duration (min) }\end{array}$ & $\begin{array}{c}\text { Irradiation } \\
\text { distance (cm) }\end{array}$ & $\begin{array}{l}\text { Harvest } \\
\text { time (h) }\end{array}$ & 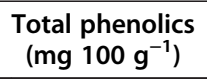 & 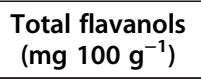 & 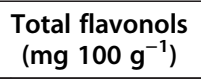 & $\begin{array}{l}\text { Catechin } \\
\left(\mu \mathrm{g} \mathrm{g}^{-1}\right)\end{array}$ & $\begin{array}{l}\text { Ferulic acid } \\
\left(\mu \mathrm{g} \mathrm{g}^{-1}\right)\end{array}$ & $\begin{array}{c}\text { Resveratrol } \\
\left(\mu \mathrm{g} \mathrm{g}^{-1}\right)\end{array}$ \\
\hline \multirow[t]{3}{*}{ Control } & & 0 & $57,50^{*} \mid$ & 4,69 i & $0,29 \mathrm{i}$ & $1,82 \mathrm{k}$ & $4,92 \mathrm{kl}$ & $1,11 \mathrm{kl}$ \\
\hline & & 24 & 71,91 ij & 4,56 i & $0,29 \mathrm{i}$ & $1,38 \mathrm{k}$ & 4,381 & $1,36 \mathrm{k}$ \\
\hline & & 48 & $43,78 \mathrm{~m}$ & 3,66 j & 0,30 i & $1,22 \mathrm{k}$ & $1,41 \mathrm{~m}$ & $1,08 \mathrm{kl}$ \\
\hline \multirow[t]{9}{*}{5} & 10 & 0 & $76,64 \mathrm{~h}$ & $5,05 \mathrm{~h}$ & $2,67 \mathrm{e}$ & $6,92 \mathrm{bcd}$ & $11,07 \mathrm{fg}$ & $5,90 \mathrm{~d}$ \\
\hline & & 24 & $96,25 f$ & $5,12 \mathrm{~h}$ & $2,46 \mathrm{e}$ & $7,53 \mathrm{~b}$ & 14,42 de & $2,98 \mathrm{gh}$ \\
\hline & & 48 & 72,99 i & $5,31 \mathrm{gh}$ & $1,03 \mathrm{~h}$ & 6,19 ef & 9,32 ghi & $3,04 \mathrm{fg}$ \\
\hline & 20 & 0 & 73,46 hi & 5,72 def & $7,12 \mathrm{a}$ & 4,34 hi & 12,41 ef & $2,45 i j$ \\
\hline & & 24 & $58,45 \mid$ & $5,90 \mathrm{~d}$ & $3,32 d$ & 3,89 i & $5,97 \mathrm{jkl}$ & $2,06 j$ \\
\hline & & 48 & $95,82 \mathrm{f}$ & 5,79 de & $3,48 d$ & 3,99 hi & 8,22 hij & $2,42 \mathrm{ij}$ \\
\hline & 30 & 0 & 135,60 b & $6,55 \mathrm{~b}$ & $3,34 d$ & 4,14 hi & $22,88 \mathrm{c}$ & $2,52 \mathrm{hi}$ \\
\hline & & 24 & 155,14 a & $6,86 a$ & $5,51 \mathrm{~b}$ & 6,70 cde & $24,28 \mathrm{c}$ & $8,43 a$ \\
\hline & & 48 & $128,44 \mathrm{~cd}$ & 7,03 a & $3,41 \mathrm{~d}$ & 7,30 bc & 31,37 a & $3,46 f$ \\
\hline \multirow[t]{9}{*}{10} & 10 & 0 & $66,50 \mathrm{k}$ & $5,12 \mathrm{~h}$ & $2,48 \mathrm{e}$ & 6,16 ef & $10,27 \mathrm{fgh}$ & $2,00 j$ \\
\hline & & 24 & 69,13 jk & $5,26 \mathrm{gh}$ & $1,03 \mathrm{~h}$ & $4,61 \mathrm{~h}$ & $10,06 \mathrm{fgh}$ & 2,53 hi \\
\hline & & 48 & $87,39 \mathrm{~g}$ & $5,06 \mathrm{~h}$ & $1,62 \mathrm{~g}$ & 6,39 de & 7,07 ijk & $2,47 \mathrm{ij}$ \\
\hline & 20 & 0 & 73,53 hi & $5,19 \mathrm{~h}$ & $3,39 d$ & $2,60 j$ & $23,12 \mathrm{c}$ & $2,95 \mathrm{gh}$ \\
\hline & & 24 & $85,16 \mathrm{~g}$ & $5,29 \mathrm{gh}$ & $3,12 d$ & 2,64 j & $16,75 d$ & $5,92 d$ \\
\hline & & 48 & 113,02 e & $5,21 \mathrm{~h}$ & $5,55 \mathrm{~b}$ & 4,22 hi & $30,81 a b$ & $7,48 \mathrm{~b}$ \\
\hline & 30 & 0 & $126,00 \mathrm{~d}$ & $6,17 c$ & $2,12 f$ & $5,58 \mathrm{fg}$ & $15,61 \mathrm{~d}$ & $6,93 \mathrm{c}$ \\
\hline & & 24 & 113,02 e & 5,60 ef & $3,17 d$ & $5,26 \mathrm{~g}$ & $28,44 \mathrm{~b}$ & 4,72 e \\
\hline & & 48 & $130,40 \mathrm{c}$ & $5,50 \mathrm{fg}$ & $2,62 \mathrm{e}$ & $8,89 a$ & $29,10 a b$ & $2,44 \mathrm{ij}$ \\
\hline
\end{tabular}

"Differences between means indicated by the same letters are not statistically significant ( $p \leq 0.05)$.

untreated calluses. Their results showed that the secondary metabolite biosynthetic capacity of Passiflora tissue cultures can be enhanced by UV irriadition.

Resveratrol (3, 4, 5-trihydroxystilbene) is a phytoalexin, which belongs to stilbene family and has important roles in the protection against fungal infections [21]. Resveratrol synthesis mainly takes place in grapevine. Recently, the attention on resveratrol significantly increased due to its importance on human health as an antioxidant, having protectory roles against coronary diseases [22] and cancer [23] and also due to its great potential to be used in medicinal, pharmaceutical, food, agriculture and cosmetic industies. In this respect, the production of this compound is important and callus cultures can be used as a source.

In this study, the production of the trans-resveratrol in callus cultures of Öküzgözü grape cultivar was changed according to the UV radiation duration, distance from callus and sampling time. The greatest trans-resveratrol content $\left(8.43 \mu \mathrm{g} \mathrm{g}^{-1}\right)$ was detected in calli exposed to UV-C for $5 \mathrm{~min}$ from $30 \mathrm{~cm}$ distance and sampled after $24 \mathrm{~h}$ and in this application trans-resveratrol was 8 fold higher than those of control calli. Our results confirmed the findings of Keskin and Kunter [24] which stated that
Öküzgözü calli exposed to UV-C produced higher amounts of trans-resveratrol when compared to untreated calli.

Cantos et al. [25] also reported that the production of the trans-resveratrol in calus culture of grape was changed depending on the duration and distance of UV-C radiation. They found the maximum trans-resveratrol yields when UV-C irradiation duration and distance were set to be $30 \mathrm{~s}$ and $40 \mathrm{~cm}$ above the grapes, respectively. Keskin and Kunter [26] studied the effects of UV$\mathrm{C}$ radiation on trans-resveratrol content of Ercis grape calli treated with two different irriation duration (10 and $15 \mathrm{~min}$ ) and found that the highest trans-resveratrol concentration was at 48 hours of 12 days-old callus cultures irradiated for $10 \mathrm{~min}$. Similarly, to induce transresveratrol, calluses were exposed to the UV-C irradiation and significant quantities of trans-resveratrol was produced by calluses of Arachis hypogaea upon UV irradiation [27].

In this research, the effects of UV-C treatments on tocopherol accumulation was also examined. UV treatments on plant calli generally focuses on phenolic compounds. With our best knowledge, there is no research on the accumulation of tocopherols in plant calli. This 
paper mentions the use of UV treatment to enhance tocopherols in calli for the first time.

Tocopherol composition of the callus samples changed significantly according to the irradiation distance, irradiation duration and incubation time $(\mathrm{P} \leq 0.05)$ and data were given Table 2. $\alpha, \beta$ and $\gamma$-tocopherols were found at different concentrations depending on the treatments, while $\delta$-tocopherol was not detected in calli of Öküzgözü. Within the calli collected at $0 \mathrm{~h}$, control group had the most abundant $\alpha$-tocopherol content compared to the UV-C treated group, independent of the duration and distance of treatment. For the calli sampled after $24 \mathrm{~h}$ and $48 \mathrm{~h}$, it was shown that 5 min UV-C treatment did not enhance $\alpha$-tocopherol content in calli and these calli had lower $\alpha$-tocopherol content than the control calli. However, when the UV-C treatment distance was increased, 10 min applications increased the $\alpha$-tocopherol concantration compared to control calli sampled after $24 \mathrm{~h}$ and $48 \mathrm{~h}$. Our data indicated that the highest $\alpha$-tocopherol concentration was found in calli exposed to UV-C for $10 \mathrm{~min}$ from $30 \mathrm{~cm}$ distance and sampled after $24 \mathrm{~h}$. On the other hand $\beta$ and $\gamma$-tocopherols were higher on control group than irradiated calli. In summary, it can be concluded that, there is a positive effect of UV irradiation on the content of $\alpha$-tocopherol depending on the irradiation duration, distance from samples and incubation time for grape calli, while UV-C treatments had no positive effect on $\beta$ and $\gamma$-tocopherol accumulation in calli. The analyses conducted in the present work revealed that these conditions are the optimum conditions which stimulate the biochemical pathways leading to $\alpha$-tocopherol accumulation.

Irradiation by all UV wavelengths damages a number of plant processes $[28,29]$. The damages of UV irradiation activate some mechanisms involving endogenous sensitizers and the generation of active oxygen species [30]. Primary radicals formed as a result of UV irradiation lead to the formation of lipid radicals, which react with oxygen to produce lipid peroxy radicals [31]. In vitro experiments have demonstrated that $\alpha$-tocopherol has the ability to terminate chain reactions of polyunsaturated fatty acid free radicals generated by lipid oxidation and therefore, $\alpha$-tocopherol acts as an efficient chain-breaking antioxidant [32].

The effects of UV irradiation on tocopherol contents change depending on the genotypes. Kacharava et al. [33] informed that kidney bean varieties and white beet responded to UV irradiation with increased levels of tocopherol, although the responses of red beet was

Table 2 The effects of UV-C treatment on tocopherols in Öküzgözü calli

\begin{tabular}{|c|c|c|c|c|c|}
\hline \multirow{2}{*}{$\begin{array}{l}\text { Irradiation } \\
\text { duration (min) }\end{array}$} & \multirow{2}{*}{$\begin{array}{c}\text { Irradiation } \\
\text { distance }(\mathrm{cm})\end{array}$} & \multirow[t]{2}{*}{ Harvest time (h) } & \multicolumn{3}{|c|}{ Tocopherols $\left(\mu \mathrm{g} 100 \mathrm{~g}^{-1}\right)$} \\
\hline & & & a tocopherol & $\beta$ tocopherol & $\gamma$ tocopherol \\
\hline \multirow[t]{3}{*}{ Control } & & 0 & $77,68^{*} \mathrm{~g}$ & $13,32 \mathrm{c}$ & $13,18 \mathrm{c}$ \\
\hline & & 24 & $133,12 \mathrm{~d}$ & $16,38 \mathrm{a}$ & $18,67 \mathrm{a}$ \\
\hline & & 48 & $106,56 \mathrm{f}$ & $15,24 \mathrm{~b}$ & $14,58 \mathrm{~b}$ \\
\hline \multirow[t]{9}{*}{5} & 10 & 0 & $67,30 \mathrm{hi}$ & 5,14 ef & 5,19 e \\
\hline & & 24 & $51,45 k$ & $1,12 i$ & $1,08 \mathrm{~h}$ \\
\hline & & 48 & 43,421 & $2,12 \mathrm{gh}$ & $4,25 f$ \\
\hline & 20 & 0 & $58,22 \mathrm{j}$ & $2,42 \mathrm{hi}$ & $2,96 f$ \\
\hline & & 24 & 43,321 & $3,45 \mathrm{gh}$ & $3,45 f$ \\
\hline & & 48 & 43,001 & $2,17 \mathrm{hi}$ & $5,42 \mathrm{e}$ \\
\hline & 30 & 0 & $62,47 \mathrm{ij}$ & 5,27 ef & $9,85 d$ \\
\hline & & 24 & $65,17 \mathrm{hi}$ & $2,14 \mathrm{hi}$ & 5,31 e \\
\hline & & 48 & $56,84 j$ & $1,16 \mathrm{i}$ & $1,00 \mathrm{~h}$ \\
\hline \multirow[t]{9}{*}{10} & 10 & 0 & 40,481 & $2,18 \mathrm{hi}$ & $3,27 f$ \\
\hline & & 24 & $82,38 \mathrm{~g}$ & $3,36 \mathrm{gh}$ & $3,86 f$ \\
\hline & & 48 & $70,42 \mathrm{~h}$ & $3,24 \mathrm{gh}$ & $2,36 \mathrm{~g}$ \\
\hline & 20 & 0 & $64,75 \mathrm{hi}$ & $3,97 \mathrm{fg}$ & 5,42 e \\
\hline & & 24 & $190,82 \mathrm{~b}$ & $3,42 \mathrm{gh}$ & $4,09 f$ \\
\hline & & 48 & 126,84 e & $3,32 \mathrm{gh}$ & $1,12 \mathrm{~h}$ \\
\hline & 30 & 0 & $51,38 \mathrm{k}$ & $3,16 \mathrm{gh}$ & $4,39 f$ \\
\hline & & 24 & $261,47 \mathrm{a}$ & $10,48 d$ & $3,42 \mathrm{f}$ \\
\hline & & 48 & $155,72 \mathrm{C}$ & $6,37 \mathrm{e}$ & $2,89 \mathrm{~g}$ \\
\hline
\end{tabular}

"Differences between means indicated by the same letters are not statistically significant ( $p \leq 0.05)$. 
not similar. Tocopherols decreased in red beets exposed to UV.

Environmental stresses including light, temperature, and oxygen affect and alter $\alpha$-tocopherol content by inducing oxidative damage [34-36]. Kozak et al. [31] found that UV-B + UV-C irradiation enhanced $\alpha$-tocopherol contents two times more in surface layers of soybean cotyledons than control and UV-B irridiated materials. They explained this situation as UV-B and UV-C irradiation affect different mechanisms at the cellular level and UV-C irradiation triggers molecular signals in common with more than one metabolic pathway.

\section{Conclusions}

In this study, the effects of UV-C irradiation on phenolic compounds and tocopherols were investigated. The results of the study showed that UV-C radiation had remarkable promoting effects on the accumulation of phenolics in the calli of Öküzgözü grape cultivar. However, further studies investigating various strategies on secondary metabolite, especially tocopherol production, should also be carried out.

\section{Methods}

Callus tissues obtained from leaf petioles of Öküzgözü grape cultivar were used as plant material. Petioles were surface sterilised with bleach (15\%) for 15 min and rinsed. Petioles were then cut into $1 \mathrm{~cm}$ pieces and placed onto solid B5 [37] culture medium with $30 \mathrm{~g} \mathrm{~L}^{-1}$ sucrose and $8 \mathrm{~g} \mathrm{~L}^{-1}$ bacto agar supplemented with $0.5 \mathrm{~g} \mathrm{~L}^{-1}$ benzylaminopurine (BA), $0.5 \mathrm{~g} \mathrm{~L}^{-1}$ indole acetic acid (IAA). The $\mathrm{pH}$ was adjusted to 5.75. All cultures were incubated in a growth cabine under dark at $25 \pm 1^{\circ} \mathrm{C}$. Induced calli were subcultured on the same media in order to maintain sufficient stock cultures.

\section{Exposure to UV-C radiation}

For investigation of the effect of UV-C irradiation on secondary metabolite production, UV-C lamp (Philips TUV-6 W, $254 \mathrm{~nm}$ wavelength, used for experimental purposes) was used as elicitor. For the elicitor applications, calli were transferred to fresh media at the same culture conditions and all experiments were carried out in $150 \mathrm{~mL}$ magenta boxes containing $50 \mathrm{~mL}$ medium and left for growth for 12 days. The UV light was applied from distances of 10, 20 and $30 \mathrm{~cm}$ for 5 (aprox. 25.2-57.6 kJ cm $\mathrm{cm}^{-2}$ ) and 10 minutes (aprox. 50.4$115.2 \mathrm{~kJ} \mathrm{~cm}^{-2}$ ) onto the 12-day-old cultures by the removal of the cover of magenta boxes inside a sterile cabin. Controls were 12-day-old cultures untreated with UV-C irradiation. Callus samples were taken at three different periods of time $(0,24$, and $48 \mathrm{~h})$ from initial calli for both the treatment and control group. Callus samples were crushed in liquid nitrogen and stored at $-20^{\circ} \mathrm{C}$ until the analyses.

\section{Extraction for phenolic compounds}

Phenolic extraction was done according to the modified procedure of Kiselev et al. [38]. Powdered callus culture sample $(2 \mathrm{~g})$ was extracted with $96 \% \mathrm{EtOH}$ overnight at a temperature of $45^{\circ} \mathrm{C}$. After, homogenate was centrifuged at $4000 \mathrm{rpm}$ for $5 \mathrm{~min}$. The supernetant was evaporated under vacuum in a rotary evaporator at $45^{\circ} \mathrm{C}$ to dryness. The dry residue was dissolved in $2 \mathrm{~mL}$ of $\mathrm{MeOH}$. After filtering through a $0.22 \mu \mathrm{m}$ Millipore filter, filtrates were directly used for spectrophotometric and HPLC analyses.

\section{Determination of phenolic compounds}

Total phenolic, total flavanols and total flavonol contents of the samples were determined spectrophotometrically using a PG Instruments T70 Plus Dual Beam Spectrophotometer (Arlington, MA, USA). Total phenolic contents were determined according to the FolinCiocalteu colorimetric method [39], calibrating against gallic acid standards and expressing the results as $\mathrm{mg}$ gallic acid equivalents (GAE) (mg $100 \mathrm{~g}^{-1}$ ). Total flavanol contents were determined according to the Arnous et al. [40], calibrating against catechin standards and expressing the results as $\mathrm{mg}$ catechin equivalents (CE) $\left(\mathrm{mg} 100 \mathrm{~g}^{-1}\right)$. Total flavonol contents were determined according to Dai et al. [41], calibrating against rutin standards and expressing the results as $\mathrm{mg}$ rutin equiva-

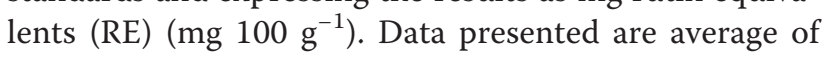
the three measurements.

HPLC analyses were carried out as previously described by Caponio et al. [42]. The HPLC system (Shimadzu Corp., Kyoto, Japan) was equipped with a pump (LC $10 \mathrm{AD}$ ), auto-sampler (SIL $10 \mathrm{AD}$ ), column oven (CTO $10 \mathrm{~A}$ ) and diode-array UV/VIS detector (DAD- $\lambda \max =$ 278). The separation was executed on a Agilent Eclipse XB C-18 (5 $\mu \mathrm{m}, 4.6 \times 250 \mathrm{~mm}$, Wallborn,Germany). The mobile phase was composed of acetic acid (2\%) and methanol with the gradient elution system at a flow rate of $0.8 \mathrm{~mL} \mathrm{~min}{ }^{-1}$. For gradient elution, mobile phase A contained 3\% acetic acid in water; solvent B contained methanol. The following gradient was used: 0-3 min, from $100 \%$ A to $95 \%$ A, $5 \%$ B; 3-20 min, from $95 \% \mathrm{~A}, 5 \%$ B to $80 \% \mathrm{~A}, 20 \% \mathrm{~B} ; 20-30 \mathrm{~min}$, from $80 \% \mathrm{~A}$, $20 \% \mathrm{~B}$ to $75 \% \mathrm{~A}, 25 \% \mathrm{~B} ; 30-40 \mathrm{~min}$, from $75 \% \mathrm{~A}, 25 \% \mathrm{~B}$ to $70 \% \mathrm{~A}, 30 \% \mathrm{~B} ; 40-50 \min 70 \% \mathrm{~A}, 30 \% \mathrm{~B}$ to $60 \% \mathrm{~A}$, $40 \% \mathrm{~B} ; 50-55 \mathrm{~min}, 60 \% \mathrm{~A}, 40 \%$ B to $50 \%$ A, $50 \%$ B; $55-65 \mathrm{~min}, 50 \% \mathrm{~A}, 50 \% \mathrm{~B}$ to $100 \%$ B. The injection volume was $20 \mu \mathrm{L}$. Samples, standard solutions and mobile phases were filtered by a $0.45 \mu \mathrm{m}$ pore size membrane filter (Millipore Co. Bedford, MA). The detection UV wavelength was set at $280 \mathrm{~nm}$. The column temperature was set at $30^{\circ} \mathrm{C}$. The compounds were quantified using Shimadzu CLASS-VP software. Catechin, ferulic acid and trans-resveratrol contents were 
determined on HPLC expressing the results as $\mu \mathrm{g} \mathrm{g}^{-1}$. Data presented are average of the three measurements.

\section{Determination of tocopherols}

The extraction of tocopherols $(\alpha, \beta, \gamma$ and $\delta$-tocopherol) were carried out as previously described by Caretto et al. [43]. Briefly, the method consisted of an alkaline hydrolysis (potassium hydroxide $60 \%$ ) followed by extraction with $n$-hexane-ethyl acetate (9:1). Chromatography separation was performed by using a Beckman HPLC Analytical System. Luna Silica $(250 \times 4.6 \mathrm{~mm}) 5 \mu$ column was used with Heptane:tetrahydrofuran (95:5) as the mobile phase. RF-10AXL Floresan dedector was used to determine tocopherols. The tocopherol content was calculated as $\mu \mathrm{g} 100 \mathrm{~g}^{-1}$ FCW (Fresh Cell Weight). Each experiment was carried out as three replicates.

\section{Statistical analysis}

Data were subjected to analysis of variance with mean separation by Duncan's multiple range test. Differences were considered statistically significant at the $p \leq 0.05$ levels. Statistical analysis was performed using SPSS 16.0 for Windows.

\section{Competing interests}

The author declares that he has no competing interests.

\section{Author's contributions}

ESC: Collection and maintenance of data and file, design and statistical analysis, writing manuscripts, critical reading of scientific literature, manuscripts and reviewers' comments and queries, corresponding author. Author read and approved the final manuscript.

\section{Acknowledgements}

The author would like to thank Professor Nilgun GOKTURK BAYDAR for her kind help to facilitate this work.

Received: 24 June 2014 Accepted: 25 August 2014

Published: 4 September 2014

\section{References}

1. Lila MA: Valuable secondary products from in vitro culture. In Plant Development and Biotechnology. Edited by Trigiano RN, Gray D. USA: New York, CRC Pres; 2005:285-289.

2. Kaur C, Kapoor HC: Antioxidants in fruits and vegetables. The millenium's health. Int J Food Sci Tech 2001, 36:703-725.

3. Traber MG, Sies H: Vitamin E in humans: demand and delivery. Annu Rev Nutr 1996, 16:321-347.

4. Argolo ACC, Sant'Ana AEG, Pletsch M, Coelho LCBB: Antioxidant activity of leaf extracts from Bauhinia monandra. Bioresour Technol 2004, 95:229-233.

5. Zhao J, Davis LC, Verpoorte R: Elicitor signal transduction leading to production of plant secondary metabolites. Biotechnol Adv 2005, 23:283-333.

6. Hotta H, Nagano S, Ueda M, Tsujino Y, Koyama J, Osakai T: Higher radical scavenging activities of polyphenolic antioxidants can be ascribed to chemical reactions following their oxidation. Biochim Biophys Acta 2002, 1572:123-132

7. Brown JP: A review of the genetic effects of naturally occurring flavonoids, anthraquinones and related compounds. Mutat Res 1980, 75:243-277.

8. Steele VE, Kelloff GJ, Balentine D, Boone CW, Mehta R, Bagheri D, Sigman CC, Zhu S, Sharma S: Comparative chemopreventive mechanisms of green tea, black tea and selected polyphenol extracts measured by in vitro bioassays. Carcinogenesis 2000, 21:63-67.
9. Fiander $\mathrm{H}$, Schneider $\mathrm{H}$ : Dietary ortho phenols that induce glutathione S-transferase and increase the resistance of cells to hydrogen peroxide are potential cancer chemopreventives that act by two mechanisms: the alleviation of oxidative stress and the detoxification of mutagenic xenobiotics. Cancer Lett 2000, 156:117-124.

10. Fryer MJ: The antioxidant effects of thylakoid vitamin $\mathrm{E}$ (a-tocopherol). Plant Cell Environ 1992, 15:381-392.

11. Flohe R, Brigelius Traber MG: Vitamin E: Function and metabolism. FASEB J 1999, 13:1145-1155.

12. Gomez Alonso S, Garcia Romero E, Hermosin Gutierrez I: HPLC analysis of diverse grape and wine phenolics using direct injection and multidetection by DAD and fluorescence. J Food Compos Anal 2007, 20:618-626.

13. Pastrana Bonilla E, Akoh CC, Sellapan S, Krewer G: Phenolic content and antioxidant capacity of muscadine grapes. J Agric Food Chem 2003, 51:5497-5503.

14. Proestos C, Bakogiannis A, Psarianos C, Koutinas AA, Kanellaki M, Komaitis M: High performance liquid chromatography analyses of phenolic substances in Greek Wines. Food Contr 2005, 16:319-323.

15. Lotito SB, Fraga CG: (+)-Catechin prevents human plasma oxidation. Free Radical Bio Med 1998, 24(3):435-441.

16. Mikio I: The influence of catechin on the antifungal effect of Amphotericin B against Candida albicans. J Oral Sci 2000, 26(1):26-31.

17. Lavola A: Accumulation of flavonoids and related compounds in birch induced by UV-B irradiance. Tree Physiol 1998, 18:53-58.

18. Karakaya S, El SN: Total phenols and antioxidant activities of some herbal teas and in vitro bioavailability of black tea polyphenols. J Agric Faculty Gaziosmanpasa University 2006, 23(1):1-8.

19. Chappel J, Hahlbrock K: Transcription of plant defence genes in response to UV light or fungal elicitor. Nature 1984, 311:76-78.

20. Antognoni F, Zheng S, Pagnucco C, Baraldi R, Poli F, Biondi S: Induction of flavonoid production by UV-B radiation in Passiflora quadrangularis callus cultures. Fitoterapia 2007, 78:345-352.

21. Hain R, Bieseler B, Kindl H, Schroder G, Stodker R: Expression of a stilbene synthase gene in Nicotiana tabacum results in synthesis of phytoalexin resveratrol. Plant Mol Biol 1990, 15:325-335.

22. Lin JK, Tsai SH: Chemoprevention of cancer and cardiovascular disease by resveratrol. Proc Natl Acad Sci U S A 1999, 23:99-106.

23. Jang JC, Leon $P$, Zhou $L$, Sheen J: Hexokinase is sugar sensor in higher plants. Plant Cell 1997, 9:5-19.

24. Keskin N, Kunter B: Production of trans-resveratrol in callus tissue of Öküzgözü (Vitis vinifera L.) in response to ultraviolet-C irradiation. J Anim Plant Sci 2010, 20(3):197-200.

25. Cantos E, Espín JC, Fernández MJ, Oliva J, Tomás-Barberán FA: Postharvest UV-C irradiated grapes as potential source for producing stilbene-enriched red wines. J Agr Food Chem 2003, 51(5):1208-1214.

26. Keskin N, Kunter B: Induction of resveratrol via UV irradiation effect in Ercis callus culture. J Agri Sci 2007, 13:379-384.

27. $\mathrm{Ku} \mathrm{KL}$, Chang PS, Cheng YC, Lien CY: Production of stilbenoids from the callus of Arachis hypogaea: A novel source of the anticancer compound piceatannol. J Agric Food Chem 2005, 53:3877-3888.

28. Stapleton AE: Ultraviolet radiation and plants: Burning questions. Plant Cell 1992, 4:1353-1358.

29. Middleton EM, Teramura AH: The role of flavonol glycosides and carotenoid in protecting soybean from ultraviolet-B damage. Plant Physiol 1993, 103:741-752.

30. Foyer $\mathrm{CH}$, Lelandais $\mathrm{M}$, Kunert $\mathrm{KJ}$ : Photooxidative stress in plants. Physiol Plantarum 1994, 92:696-717.

31. Kozak RG, Ricco RA, Gurni AA, Boveris AD, Puntarulo S: Antioxidant response of soybean cotyledons (Glycine max) to ultraviolet irradiation. Can J Plant Sci 1999, 79:181-189.

32. Havaux M, Eymery F, Porfirova S, Rey P, Dörmann P: Vitamin E protects against photoinhibition and photooxidative stress in Arabidopsis thaliana. Plant Cell 2005, 17:3451-3469.

33. Kacharava N, Chanishvili S, Badridze G, Chkhubianishvili E, Janukashvili N: Effect of seed irradiation on the content of antioxidants in leaves of kidney bean, cabbage and beet cultivars. Aust J Crop Sci 2009, 3(3):137-145.

34. Wise RW, Naylor AW: Chilling-enhanced photo-oxidation. Evidence for the role of singlet oxygen and superoxide in the breakdown of pigments and endogenous antioxidants. Plant Physiol 1987, 83:278-282. 
35. Tanaka K, Masuda R, Sugimoto T, Omasa K, Sakai T: Water deficiencyinduced changes in the contents of defen-sive substances against active oxygen in spinach leaves. Agric Biol Chem 1990, 54:2629-2634.

36. Ushimaru T, Shibasaka M, Tsuji H: Resistance to oxidative injury in submerged rice seedlings after exposure to air. Plant Cell Physiol 1994, 35:211-218.

37. Gamborg OL, Miller RA, Okajima K: Nutrient requirements of suspension cultures of soybean root cells. Exp Cell Res 1968, 50:151-156.

38. Kiselev KV, Dubrovina AS, Veselova MV, Bulgakov VP, Fedoreyev SA, Zhuravlev YN: The rolB gene-induced overproduction of resveratrol in Vitis amurensis transformed cells. J Biotechnol 2007, 128:681-692.

39. Singleton VL, Rossi JR: Colorimetry of total phenolics with phosphomolybdic phosphotungstic acid. Am J Enol Viticult 1965, 16:144-158.

40. Arnous A, Makris DP, Kefalas P: Effect of principal polyphenolic components in relation to antioxidant characteristics of aged red wines. J Agr Food Chem 2001, 49(12):5736-5742.

41. Dai GH, Andary C, Mondolot L, Boubals D: Involment of phenolic compounds in the resistance of grapevine callus to downy mildew (Plasmopara viticola). Eur J Plant Pathol 1995, 101:541-547.

42. Caponio F, Alloggio V, Gomes T: Phenolic compounds of virgin olive oil: Influence of paste preparation techniques. Food Chem 1999, 64:203-209.

43. Caretto S, Speth B, Fachechi C, Gala R, Zacheo G, Giovinazzo G: Enhancement of vitamin E production in sunflower cell cultures. Plant Cell Rep 2004, 23:174-179.

doi:10.1186/0717-6287-47-37

Cite this article as: Cetin: Induction of secondary metabolite production by UV-C radiation in Vitis vinifera L. Öküzgözü callus cultures. Biological Research 2014 47:37.

\section{Submit your next manuscript to BioMed Central and take full advantage of:}

- Convenient online submission

- Thorough peer review

- No space constraints or color figure charges

- Immediate publication on acceptance

- Inclusion in PubMed, CAS, Scopus and Google Scholar

- Research which is freely available for redistribution 